\title{
Technical and Economic Efficiency of Smallholder Arabica Coffee Farming in Panti Sub-district, Jember
}

\author{
Dani Widjaya $^{1^{* *}}$, Yuli Hariyati ${ }^{1)}$ and Djoko Soejono ${ }^{1)}$ \\ ${ }^{1)}$ Agribussiness Study Program, Agriculture Faculty, University of Jember, Jl. Kalimantan, Jember, Indonesia \\ *)Coresponding author: widjayadani94@gmail.com
}

\begin{abstract}
Many factors must be considered in coffee production processes. Use of factors of production must also be efficient in order to produce maximum production. This research was conducted in Panti Sub-district, Jember, as one of larger coffee producer in Jember. This location was also one area in Jember cultivated with Arabica coffee since 2012. Therefore, this study aimed to determine production factors in Arabica coffee smallholders; particularly technical and economic efficiency of Arabica coffee smallholders. Research method including interview and secondary data collection was carried out in three farmer groups in Panti Sub-district. Samples included 36 farmers from Surya Tani, Sejahtera Bersama and Taman Putri farmer groups. Analytical methods used were Cobb Douglass as a function of Stochastic Frontier to see the technical efficiency of farming and analysis of economic the selected efficiency with pricing approach. Technical efficiency in Arabica coffee farming in the selected locations were considered efficient in the level of $71.4 \%$ with a minimum of technical efficiency of $24.9 \%$ and a maximum efficiency of $93.4 \%$. Economic efficiency showed that factors of labor and use of organic fertilizers were not efficient, thus there should be a reduction in use of labor and organic fertilizers. The factors indicated also that use of inorganic fertilizers was not efficient, with economic efficiency value (NPM/Px) of 1.579. The conditions indicate that there is a need to use of inorganic fertilizers to be an economically efficient manner.
\end{abstract}

Keywords: Arabica coffee, production, technical efficiency, economic efficiency

\section{INTRODUCTION}

Indonesia is the fourth largest coffee producer in the world. In 2014, Indonesia produced 685,000 ton coffee and $95 \%$ of it was dominated by product of smallholder plantations (BPS Indonesia, 2014). Coffee is one of famous Indonesian valuable commodities. Until now, various kinds of coffee cultivation have been developed by farmers, from conventional system until organic coffee cultivation (Winarni et al., 2013).
One of large coffee producers in Indonesia is East Java Province. According to Indonesian Central Bureau of Statistics (2014), East Java Province is the fourth largest coffee producer after South Sumatera, Lampung and North Sumatera. Average coffee production in East Java in 2012-2014 was 56,756 ton per year.

Most of coffee plantation in East Java is smallholder plantation. According to Disbun Jatim (2015), the area of smallholder plantations was larger and more productive than 
large plantations. The growth of plantation area showed high percentage which was $2.17 \%$ per year. However, growth of smallholder plantations was still lower than state owned plantations. The growth of smallholder plantation production in East Java was $1.43 \%$ per year. It was lower than the growth of state owned plantation production which was $9.86 \%$ per year.

The main coffee growing areas in East Java are Malang and Jember Districts. According to BPS Jatim (2013), the average production of coffee in Jember was 2,880 tons while in Malang was 7,788 tons. Coffee is one of main commodities in Jember District which has a number of productive coffee plantations, especially smallholder plantations. The one of high coffee production areas districts in Jember District is Panti Sub-district. According to Disbun Jember (2014), in 2014 Panti Subdistrict produced 1.9 tons of coffee, the second after Silo Sub-district with 12.5 ton. However, Panti Sub-district has the potential to be cultivated with Arabica coffee. Arabica coffee plantation in Panti began with government assistance in 2012. The first planting was in 2012 and the first production was in 2015. The Arabica coffee plantation in Panti is not intensive in utilizing plantation inputs. Moreover, the farmers are reluctant to take risk in their business. Utilization of input was less intensive because Government only provided coffee seeds without any further assistance in the process of production.

The utilization of farming input combination has to be conducted as efficient as possible by farmers. The achievement of input combination to obtain highest output is called technical efficiency. Farmers has to think to get maximum profit from their farms. Utilization of the most efficient input combination with minimum cost is called economic efficiency.
Allocation of production, labor and capital such as fertilizer become one of major determining factors to achieve optimum production. Utilization of those production factors influence the profit. On the other hand, limited land area and labor resources require farmers to allocate the input as efficiently as possible to gain maximum profit. Therefore, it is necessary to check whether production factors have been utilized in their maximum capacity. Knowledge about optimum input allocation is expected to improve technical and economic efficiency of small holder Arabica coffee cultivation in Panti Sub-district, Jember.

According to a research by Risandewi (2013), there are several factors which influence production of Robusta coffee in Temanggung District such as land area, number of labor, number of coffee plants, use of fertilizer, and coffee plant age. A research by Thamrin (2014) found that there were 10 factors which influenced the production of Arabica coffee in Enrekang District, such as land area, number of plants, use of urea, ZA, SP36, KCl, pesticide, herbicide, manure and labor. Fauziyah (2010) found that there were four influencing inputs in tobacco cultivation namely seed, urea, TSP fertilizer and manure, while $99 \%$ of production variation was caused by technical efficiency. Nakanwagi (2015) found that there was a potential of $32 \%$ for milk producers to improve their technical efficiency. A research by Muflikah (2015) showed that cultivation of shaded grown tobacco in PTPN X Ajong Gayasan Plantation, Jember had not achieved its maximum capacity because it was technically efficient but not economically efficient. The aims of this research were to determine factors that influence Arabica coffee production, to calculate technical and economic efficiency of Arabica coffee cultivation in Panti Subdistrict, Jember. 


\section{MATERIALS AND METHODS}

The study was conducted in Panti Subdistrict, Jember District. wich was chosen after receiving Government assistance to cultivate Arabica coffee since 2012 and its first Arabica coffee production was in 2015. This study employed descriptive and analytic methods. According to Sugiyono (2008), cluster sampling is an area sampling technique which is used to determine sample from a vast population. Panti Sub-district consisted of many villages having coffee farmer groups which were Pono, Antokan, Surya Tani, Sumber Mulyo, Sejahtera Bersama, Taman Putri, Karya Tani, Pakis Jaya, Cempoko, dan Kemundungan. The farmer groups were spread in four villages in Panti Sub-district.

There were 336 coffee farmers in Panti Sub-district. Before conducting cluster sampling, farmer groups were chosen purposively cultivate Arabica coffee. According to Sandjaja (2011), purposive sampling is sampling which is chosen based on subjective consideration of the researcher. Therefore, Surya Tani, Sejahtera Bersama and Taman Putri farmer groups were chosen as the objects of this study.

Based on Slovin formula, the samples were 32 Arabica coffee farmers. It was more than the minimum requirement for the research sample. In addition, the sample was more than $25 \%$ of the population. Number of the samples based on Slovin formula was the minimum samples for research. Therefore, 36 samples were taken as objects of the research. The samples were taken by proportionate cluster random sampling.

The first research problem about factors which influence coffee production in Panti Sub-district, Jember region was analyzed by using Cobb Douglas production function. There are several factors which influence the production of coffee, such as land area, number of labor, number of coffee plants, use of fertilizer and age of the coffee plants. The factors can be put in the Cobb Douglas equation as follow:

$$
\mathrm{Y}=\mathrm{b}_{0} \mathrm{X}_{1}^{\mathrm{b} 1} \mathrm{X}_{2}^{\mathrm{b} 2} \mathrm{X}_{3}^{\mathrm{b} 3} \mathrm{X}_{4}^{\mathrm{b} 4} \mathrm{X}_{5}^{\mathrm{b} 5} \mathrm{e}^{\mathrm{u}}
$$

It can be put in natural Log as follow:

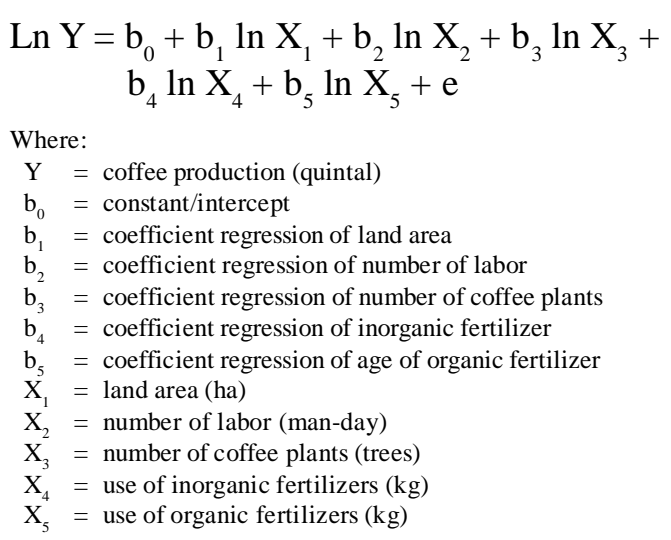

Statistic test used:

$$
\mathrm{F}=\frac{\mathrm{RK}_{\text {regression }}}{\mathrm{RK}_{\text {residua }_{1}}}
$$

Coefficient of determination illustrates part of the total variation which can be explained by the model. If the value of $\mathrm{R}^{2}$ is closer to 1 , it can be considered more accurate. The characteristics of coefficient of determination are as follow (Setiawan \& Kusrini, 2010):

$$
\text { Value of } \mathrm{R}^{2}=\frac{\mathrm{JK}_{\text {regression }}}{\mathrm{JK}_{\text {correlated }}}
$$

Individual test is used to test whether coefficient regression of each independent variable significantly influence dependent variable. The hypothesis in this test is as follow:

$$
\mathrm{t}_{\text {value }}=\frac{\mathrm{bi}}{\mathrm{Sb}_{\mathrm{i}}}
$$

Value of t-value is compared with value of $t_{(a / 2, n-p)}$. The second research problem 
about the capacity of coffee production in Panti region can be analyzed using approach of technical efficiency of a business. Technical efficiency test is conducted using CobbDouglas equation with frontier regression approach. Asmara \& Sugianto (2009) stated that hypothesis that the plantation has reached efficiency should be tested by using Likelihood ratio test (LR).

This hypothesis states that $\sigma \mathrm{u}^{2}=0$ which means $y=\sigma u^{2} / \sigma v^{2}=0$ and the value of nedf $=0$. Rachmina \& Maryono (2008) argued that the number did not indicate technical inefficiency in production function model, thus production function model represented empirical data.

The next step is examining effect comparison between error caused by external factor and error caused by internal factor (technical inefficiency). Battese \& Corra cit. Coelli (2005) replaced $\sigma u^{2}$ with $\sigma^{2}=\sigma u^{2}+$ $\sigma v^{2}$ and $\gamma=\sigma u^{2} /\left(\sigma u^{2}+\sigma v^{2}\right)$ the value of $\gamma$ had to be between 0 and 1 . The value of $\gamma$ shows comparison ration between variant of technical inefficiency and variant caused by random error.

Achievement of technical efficiency can be observed through the value of LR test. The result can be completed by the value of LR-test in OLS method and the value of LR-test using maximum likelihood estimation method. The test can be calculated by the following formula of LR-test (Coelli, 2005):

$$
\mathrm{LR}=-2[\ln (\mathrm{Lr})-\ln (\mathrm{Lu})]
$$

The result of LR calculation above is then compared with critical value of $x^{2}$. The test criteria used is one-way generalized likelihood ratio.

Technical efficiency measures actual production with potential production. The formula used to determine the value of technical efficiency is based on Coelli et al. (2005) as follow:

$$
\mathrm{TE}=\frac{\mathrm{Y}_{\mathrm{i}}}{\exp \left(\mathrm{X}_{\mathrm{i}} \mathrm{b}+\mathrm{v}_{\mathrm{i}}\right)}=\exp \left(\mathrm{u}_{\mathrm{i}}\right)
$$

The value of technical efficiency is considered efficient if the value is more than 0.70 as the efficient limit (Coelli, 1998).

The third research problem about economic efficiency of Arabica coffee plantation was analyzed using price efficiency approach. Price efficiency is achieved by comparing between marginal productivity for each input $\left(\mathrm{VMPx}_{\mathrm{i}}\right)$ and input price $\left(\mathrm{v}_{\mathrm{i}}\right)$. Analysis of price efficiency can be done by using following formula (Soekartawi, 2013):

$$
P_{x}=\frac{b \cdot Y P_{y}}{X}
$$

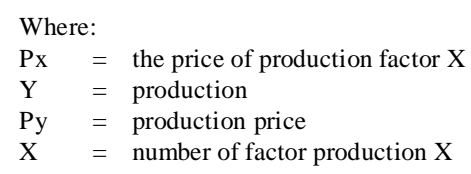

\section{RESULTS AND DISCUSSION}

\section{Factors Influencing Coffee Production}

Arabica coffee cultivation by smallholders in Panti Sub-district, Jember, was started in 2012, thus until 2015 they only had experienced one harvest. All of the plants were three years old in 2015. This research only observed the input management in 2015. The Arabica coffee cultivation by smallholders in Panti Sub-district was predicted being influenced by several production factors, which were land area $\left(\mathrm{X}_{1}\right)$, labor $\left(\mathrm{X}_{2}\right)$, plant number $\left(\mathrm{X}_{3}\right)$, inorganic fertilizer $\left(\mathrm{X}_{4}\right)$, and organic fertilizer $\left(\mathrm{X}_{5}\right)$. According data gathered in the field regarding production and factors influencing the production, the analysis results presented in Table 1.

Based on Table 1, the constant of this model was -5.03 . The value of sigma-squared 
Technical and economic efficiency of smallholder Arabica coffee farming in Panti Sub-district, Jember

Table 1. Regression coefficient values of factors influencing smallholder Arabica coffee production in Panti Sub-district

\begin{tabular}{lccc}
\hline Independent variabel & \multicolumn{1}{c}{ Regression coeffision } & \multicolumn{1}{c}{ Std. error } & t-calculated \\
\hline Labor & $-0.786 \times 10^{-9}$ & $0.214 \times 10^{-9}$ & $-3.67 *$ \\
Inorganic fertilizer & 2.04 & 0.321 & $6.35 *$ \\
Organic fertilizer & $0.207 \times 10^{-8}$ & $0.478 \times 10^{-9}$ & $4.33 *$ \\
Constant & $-0.503 \times 10($ anti $\mathrm{Ln}=0.00653)$ & & \\
Sigma-squared & 0.131 & & \\
Log-likelihood ratio & -11.586 & & \\
t-tabel $(\alpha=0.05)$ & 2.03951 & &
\end{tabular}

on OLS estimation was 0.131 . If the value of sigma-squared $=0$, thus there was no influence of technical efficiency in this model. The test result using this method did not show any value of gamma estimation. The value of gamma was needed to see residual percentage on this model which was influenced by technical inefficiency and error term and the value of log-likelihood ratio by -11.586 . The following was the production function equation based from the analysis:

$$
\begin{aligned}
\operatorname{Ln}(\mathrm{Y})= & (-5.03)-0.786 \times 10^{-9} \operatorname{Ln}\left(\mathrm{X}_{2}\right) \\
& +2.04 \operatorname{Ln}\left(\mathrm{X}_{4}\right)+0.207 \mathrm{x} \\
& 10^{-8} \operatorname{Ln}\left(\mathrm{X}_{5}\right)+\varepsilon
\end{aligned}
$$

thus, the model of Cobb-Douglas function from the result of $\mathrm{Ln}$ value was:

$$
\begin{aligned}
& \mathrm{Y}=0.00653 \mathrm{X}_{2}^{-0.786 \times 10^{-9}} \mathrm{X}_{4}^{2.04} \mathrm{X}_{5}^{0.207 \times 10^{-8}} \mathrm{e}^{\mathrm{a}} \\
& \text { Where: } \\
& \mathrm{Y}=\text { Arabica coffee production }(\mathrm{kg}) \\
& \mathrm{b}_{0}=\text { Constant } \\
& \mathrm{X}_{2}=\text { Labor (man-day) } \\
& \mathrm{X}_{4}=\text { Inorganic fertilizer }(\mathrm{kg}) \\
& \mathrm{X}_{5}=\text { Organic fertilizer }(\mathrm{kg})
\end{aligned}
$$

According to the analysis result, production of Arabica coffee without any addition of labor, inorganic fertilizer and organic fertilizer variables was $0.00653 \mathrm{~kg}$. The next test would be interpretations of each individual independent variables (labor, inorganic fertilizer, and organic fertilizer) toward dependent variable (Arabica coffee production).

\section{Labor Force}

Regression coefficient of labor force variable was $-0.786 \times 10^{-9}$ which meant contrary influence between labor force inputs and Arabica coffee production. The result showed the value of t-test and the value of $t$-value by -3.67 respectively larger than $t$-table. The value suggested that labor force variable actually influenced the Arabica coffee production which meant by ceteris paribus assumption each $1 \%$ addition of labor force input would reduce the production of Arabica coffee by $0.786 \times 10^{-9} \%$. The coefficient value also represented elasticity of labor force factor. The value of $-0.786 \times 10^{-9}$ showed that labor force input application was Ep < 1 elasticity. The value showed that the application of labor force was at irrational Zone 2, which meant the farmers did not need to add more labor force because that would reduce production.

The labor force used in the Arabica coffee cultivation included labor forces from both inside and outside farmers family. Labor forces inside the family were more commonly used by the farmers than the labor forces outside the family. The labor forces outside their families were from the area around the Arabica coffee plantations. The average labor force used in the Arabica coffee cultivation was 159 mandays. This condition would greatly influence many of the cultivation processes. Most of the labor forces were not familiar with the appropriate way of Arabica coffee cultivation system, thus which would 
reduce much of the production especially in harvest time. A large number of labor forces who were not skilled would decrease the production caused by damages made by those workers. Therefore, owner farmer should provide their workers annual socialization to make the workers to know the proper and correct ways of Arabica coffee cultivation.

Referring to Mandei (2015), too many labor forces reduce production of any business, which is also supported by Rakhmawati (2011) that when labor force had reached maximum number it eventually decrease production meanwhile more addition of it will increase the labor fee. According to Fitriani \& Zaini (2012), the labor force flow on catfish farming in the research location was exaggerating, that caused production reduction.

\section{Inorganic Fertilizer}

Regression coefficient of inorganic fertilizer was 2.04 which meant that the change of inorganic fertilizer variable was equivalent to the change of the Arabica coffee production. Individual testing using t-test, $\mathrm{t}$-value was 6.35 which was larger than the t-table 2.039 which indicated that inorganic fertilizer variable actually influenced Arabica coffee production. The regression coefficient of inorganic fertilizer variable was 2.04, which meant by the assumption (of ceteris paribus) every $1 \%$ addition of inorganic fertilizer would increase the production by $2.04 \%$. The coefficient value also represents the elasticity of the inorganic fertilizer production factor. The value of 2.04 showed that inorganic fertilizer input application was Ep > 1 of elasticity; that was the value which showed that inorganic fertilizer was on irrational Zone 1, which meant the farmers should add more inorganic fertilizer input to enter Zone 2 where rational zone for input management.
Types of fertilizer used in the Arabica coffee cultivation were urea, ZA and Ponska fertilizers. The average use fertilizers were urea $416.2 \mathrm{~kg}$, ZA $407 \mathrm{~kg}$, and Ponska $207 \mathrm{~kg}$ per ha. The usage of those fertilizers was insufficient according to the recommendation of Indonesian Coffee and Cocoa Research Institute (ICCRI).

The use of fertilizers recommended by ICCRI had been increasing for each year. The third year of the usage of the fertilizers recommended by ICCRI was $640 \mathrm{~kg} / \mathrm{ha}$ (Nur et al., 2015). The third year was the year when the research of the Arabica coffee cultivation of smallholders in Panti Sub-district, Jember was conducted. On the third year, the farmers used $344 \mathrm{~kg} / \mathrm{ha}$ in average of inorganic fertilizers meaning that the inorganic fertilizer application was still insufficient according to the recommendation of ICCRI.

Based on research of Thamrin (2014), Urea and ZA fertilizers brought positive outcome on Arabica coffee production, which suggest that the fertilizer application increment would be followed by the increased coffee production until certain extend. However, urea, ZA, or Ponska fertilizers had to be controlled in order to prevent environmental damage. Referred to the research of Apsari (2009), chemical fertilizer usage had to be applied with caution in health perspective because they might cause damaging effect, thus there should be other alternative fertilizer with the same benefits by development of those fertilizers.

\section{Organic Fertilizer}

Regression coefficient of organic fertilizer variable was $0.207 \times 10^{-8}$ which meant that organic fertilizer variable had positive relationship on Arabica coffee production. The value of individual testing using t-test was higher than t-table 2.039 which meant 
that organic fertilizer variable actually influenced Arabica coffee production and by assumption (of ceteris paribus) that every $1 \%$ addition of organic fertilizer would increase the production by $0.207 \times 10^{-8} \%$ with Ep < 1 of elasticity meaning that organic fertilizer was on rational zone. This results indicated that the farmers were already efficient in organic fertilizer usage, where each input addition the output would increase even if the addition (marginal product) had been decreasing, the total production would be increasing.

Organic fertilizers used by the Arabica coffee farmers were homemade fertilizers bought from agriculture shops. The farmers used $2,625 \mathrm{~kg} / \mathrm{ha}$ per year in average of organic fertilizers. The use of organic fertilizers was similar to the usage of inorganic fertilizers applied in the beginning and in the end of rainy season. The use of organic fertilizers was meant to offset the use of inorganic fertilizers. A continuing usage of inorganic fertilizers tends to damage soil, thus the usage of organic fertilizer was meant to balance the bad effect of inorganic fertilizers usage.

The research of Darmansyah (2013) showed that organic fertilizers gave positive effect on maximum production, thus by the addition of organic fertilizers meant would increase production. According to Kartasapoetra cit. Rakhmawati (2011), use of organic fertilizers is essential because it can improve soil structure and increase water absorption capacity, and provide nutrients needed by plants.

\section{Data Customization}

According to the analysis result, two variables, i.e. land area and number of plants from the model caused the variables were not corresponding to the classical assumption which can be explained three data customization.

\section{Data customization 1}

Data customization 1 was utilized by research sample data testing, with 36 coffee farmers where production factors including land area $\left(\mathrm{X}_{1}\right)$, labor force $\left(\mathrm{X}_{2}\right)$, number of the plants $\left(\mathrm{X}_{3}\right)$, organic fertilizer $\left(\mathrm{X}_{4}\right)$, and inorganic fertilizer $\left(\mathrm{X}_{5}\right)$. The results showed that there were outliers data from labor force, number of the plants and organic fertilizer factors which had great influence over data normalization deviation. Data normalization test could be viewed from the plot where there were some data separated from the diagonal line, which meant there were deviations from data normalization. One way to overcome that problem was by getting the outliers off from the observed data (Paludi, 2009). According to Ghozali (2011), spreading data could show the heteroscedasticity tests, if there were certain patterns, such as some points forming certain regular patterns (waves, expanding then narrowing), that indicated the existence of heteroscedasticity. The heteroscedasticity test with partial regression plot did not result in forming certain pattern of spreading data, which showed homoscedasticity of the data.

Multicollinearity tests in observing simple correlations between the five production factors displayed that land area variable was highly correlated with labor force variable for 0.907 , with number of the plants variable for 0.903 and with inorganic fertilizer variable for 0.916. High simple correlations were also presented in number of plants with land area variable for 0.903 , and with labor force variable for 0.928 in correlation number. Multicollinearity also existed on land area factor by 10.623 > $10 \mathrm{VIF}$ value. 
Lains (2003) stated that in a case where a variable had multiple collinearity which influence was relevant toward other independent variables, the variable might be excluded from the model, thus, to avoid problems on the model, in this case land area variable was excluded from the model. The reason for the variable exclusion was that the simple correlation value $(0.90)$ was approaching 1 . Wibowo (2000) suggested that to solve multicollinearity problem was by omitting one from two variables which had relatively higher simple correlation. According to Harianti (2012), if $r>0.9$, the correlation is very high or very strong.

The strong correlation of land area variable occured because the farmers consider land unit as the major production factor. Based on the suggestion of ICCRI, the farmers should plant $\mathrm{S}$-line coffee variety in space of $2.5 \mathrm{~m} \times 2.5 \mathrm{~m}$, there would be around 1600 plants in one hectare. It happened to the inorganic fertilizer variable as well. In one ha land area, generally the farmers use $300 \mathrm{~kg}$ of Urea, $300 \mathrm{~kg}$ of ZA, and $150 \mathrm{~kg}$ of Ponska fertilizers. That condition showed the strong relationship between land area factor and other production factors. The land where the farmers use to cultivate Arabica coffee based on certain right (cultivation right title, Hak Guna Usaha) plantation, thus the farmers can not enlarge the area due to Government regulation.

The value of Adj $\mathrm{R}^{2}$ presented a strong influence between independent variables and the dependent variable (Arabica coffee production) by $92.6 \%$, that meant the dependent variable (Arabica coffee production) was influenced by independent variables (land area, labor force, plants, inorganic and organic fertilizer) by $92.6 \%$ while the other $7.4 \%$ was influenced by other variable outside this model. Significance value was less than 0.05 indicated that independent variables influenced the dependent variable together.

\section{Data customization 2}

Data customization 2 was done by excluding one outlier from research samples, thus, with 35 farmers as samples and the land area variable was removed from the model. Therefore, there were four independent variables, which were labor force, number of plants, inorganic fertilizer, and organic fertilizer. Referred to the second simulation result, it was found that there was one outlier remaining. The analysis also resulted in no deviation of data normalization, displayed in the plot chart. The heteroscedasticity tests on partial regression plot also did not show any heteroscedasticity of the data.

Based of simple multicollinearity value, there was a strong relationship between number of plants variable and labor force variable by 0.903 but there was no any variable with FIV > 10. Number of plants had high correlations with land area, labor force and inorganic fertilizer factors because plant was the main component in agriculture, that means that the more plants were planted, the more production factors were used as well. The plants cultivated by the farmers in Panti were from Government assistance, thus, the distribution is adjusted based on the size of land area, that is also make the correlation between plants and land very strong.

The Adj $R^{2}$ value was 0.845 indicated that dependent variable (Arabica coffee production by smallholders) was affected by independent variables (labor force, inorganic and organic fertilizers) by $84.5 \%$ and the other $15.5 \%$ was the effect of other factors outside this model. Significance value $<0.05$, meant that the independent variables influenced the dependent variable. 


\section{Data customization 3}

Data customization 3 was done by removing one outlier, so there were 34 farmers as samples with 3 variables, (labor force, inorganic fertilizer, and organic fertilizer). According to this third simulation, there was no outlier found. Data normalization test showed that there was no deviation data normalization as presented in P-plot chart. The data spreading was random and formed no certain pattern as well, suggested no heteroscedasticity data problem.

The simple data multicollinearity test occurred between labor force factor and inorganic fertilizer, by 0.846 indicated this multicollinearity condition did not influence this model. A full multicollinearity test also did not show any result for the third simulation calculation, considering that there was no independent variable with FIV $>10$.

The summary model table showed that the independent variable influenced the dependent variable by $79.7 \%$. Anova table displayed that together the independent variables (labor force, inorganic, and organic fertilizer) influenced the dependent variable (Arabica coffee production). Referred to the analysis, factors influencing coffee production were labor force, inorganic fertilizer and organic fertilizer. The first hypothesis mentioned that the factors influencing Arabica coffee production in Panti Subdistrict of Jember District are the land area, labor force, number of plants, inorganic and organic fertilizer. However, only labor force, inorganic fertilizer and organic fertilizer had the real impact on Arabica coffee production of smallholders in Panti Sub-district, Jember. Land area and number of plants variables were not included in this model because those variables had a high correlation with labor force variable. It indicated that land area, number of the trees and labor force variables had a very strong connection.

\section{Technical Efficiency Analysis}

The result of technical efficiency analysis could be observed from prediction of the parameters of the frontier production function that presented that variables influencing Arabica coffee production were labor force, inorganic fertilizer and organic fertilizer, even though, that were inorganic fertilizer and organic fertilizer variables which had significant effect. The model prediction test using maximum likelihood estimation (MLE) method as presented in Table 2 .

According to Table 2, it can be seen that sigma squared value in MLE method is 0.256 indicated that the distribution of inefficiency $\left(u_{i}\right)$ error term is normally distributed, thus, production function is assumed representing the empirical data. Gamma $(\gamma)$ value displayed technical inefficiency $\left(u_{i}\right)$ varieties and varieties that were caused of random error $\left(\mathrm{v}_{\mathrm{i}}\right)$ in the model.

Table 2. Predicted parameters of frontier production function of variables of labor, inorganic fertilizer, and organic fertilizer

\begin{tabular}{lccr}
\hline Variable & Coefficient & \multicolumn{1}{c}{ Std. error } & t-calculated \\
\hline Labor $\left(\mathrm{X}_{2}\right)$ & $-0.949 \times 10^{-9}$ & $0.179 \times 10^{-8}$ & -0.528 \\
Inorgani fertilizer $\left(\mathrm{X}_{4}\right)$ & 2.05 & 0.0729 & $28.0 *$ \\
Organic fertilizer $\left(\mathrm{X}_{5}\right)$ & $0.20 \times 10^{-8}$ & $0.106 \times 10^{-9}$ & $19.4 *$ \\
Sigma-squared & 0.256 & Technical efficiency & 0.7135 \\
Gamma & 0.8969 & $\mathrm{t}$-table $(\alpha=0.05)$ & 2.0395 \\
Log-likelihood ratio & -9.581 & $\chi^{2}$-table $(\alpha=0.05)$ & 2.706 \\
LR test of the one sided error & 4.01 & & \\
\hline
\end{tabular}

Notes (*): significantly level $95 \%$. 
Gamma value in the analysis result using MLE method indicated that $89.69 \%$ error term in the model was arised from technical inefficiency, while other was arised from random error, also the value represented the gap between maximum production and production reached, which were brought rather by random error outside the model than technical inefficiency error.

Likelihood ratio (LR) value test is meant to show the whole technical efficiency achievement. The analysis test displayed LR test value by 4.01 . LR value testing could also be conducted using this equation:

$\mathrm{LR}=-2[\ln (\mathrm{Lr})-\ln (\mathrm{Lu})]$

$\mathrm{LR}=\quad-2[-11.586-(-9.581)]$

$\mathrm{LR}=-2(-2.005)=4.01$

The calculation result value showed there was technical inefficiency effect toward variety of disturbing error at the smallholder Arabica coffee cultivation in Panti Sub-district of Jember District or for the whole cultivation technology did not represent constant return to scale condition. Figure 1 shows technical efficiency achievement on each farmer:

Figure 1 shows technical efficiency achievement of 34 Arabica coffee farmers of Panti Sub-district. The highest efficiency achievement was on $>0.8$ efficiency level from $32.35 \%$ farmers and the smallest technical efficiency was on $0.2-0.5$ efficiency level from three farmers or $8.82 \%$. An effort is technically efficient if the technical efficiency value is $>0.7$ (Coelli, 1998). Figure 1 shows that there were 17 farmers or $50 \%$ were already technically efficient. Table 3 presents statistical result of technical efficiency achievement of the Arabica coffee cultivation of smallholder in Panti Sub-district of Jember District.

According to Table 3, the Arabica coffee cultivation of smallholders in Panti Subdistrict of Jember District reached technical efficiency value by $0.2491-0.9337$. The value showed that the farmers could reach

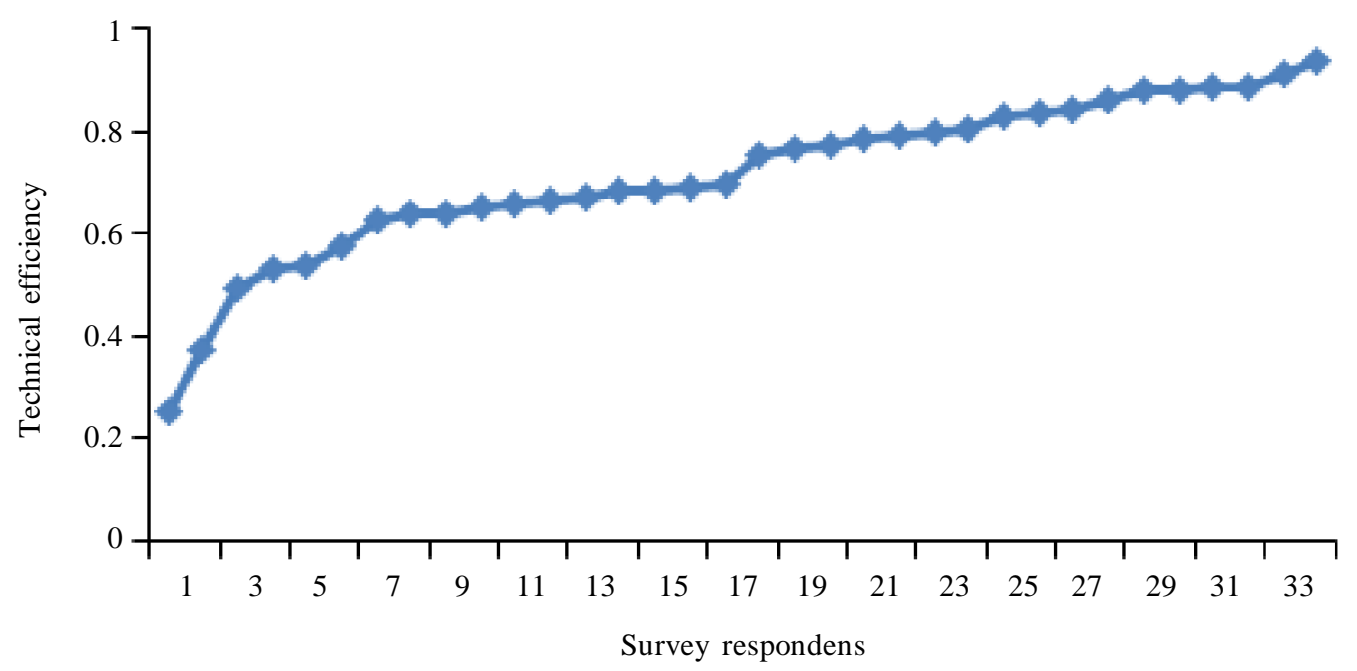

Figure 1. Technical efficiency (from small to high) achievement Arabica coffee smallholder farming in the Panti Sub-district of Jember District 2015 
$24.91 \%$ potential product from the combination of labor force, inorganic fertilizer and organic fertilizer inputs. The maximal value showed by the farmers was 0.9337 or the farmers were capable to reach efficiency by $93.37 \%$ potential production with the combination of labor force, inorganic fertilizer and organic fertilizer inputs. The average technical efficiency of the Arabica coffee cultivation was $0.7135>0.7$, which meant the Arabica coffee cultivation was technically efficient. Frequency distribution achievement of technical efficiency the Arabica coffee cultivation in Panti Sub-district of Jember District is explained in Table 4.

According to Figure 2, the Arabica coffee cultivation in Panti Sub-district of Jember District was still incapable to reach the best technical efficiency. Generally technical efficiency achievement of the Arabica coffee cultivation was 0.7135 , this condition showed that 0.2865 opportunity for the farmers to achieve the maximum technical efficiency using the combination of labor force, inorganic fertilizer and organic fertilizer inputs. The reason why the farmers could not achieve the maximum technical efficiency yet was because they did not use the inputs properly and correctly, thus, there was technical inefficiency that caused them unable to reach the maximum technical efficiency.

Based on the analysis result, there were $50 \%$ of the farmers who were not technically efficient yet indicated that 17 farmers were capable to reach $\mathrm{TE}<0.7$ potential production that could be achieved by using inputs combination. This condition occurred because the farmers did not use the inputs properly and correctly, thus, they could not achieve the technical efficiency. The average technical efficiency of 0.7135 , meaning that those Arabica coffee farmers in the area studied were technically efficient (Table 4).

Teble 3. Statistical description of the technical efficiency achievement of smallholder Arabica coffee farming in Panti Subdistrict, Jember

\begin{tabular}{lc}
\hline Statistic discription & Technical efficiency achievement \\
\hline Minimum & 0.2491 \\
Maximum & 0.9337 \\
Mean & 0.7135 \\
\hline
\end{tabular}

Tabel 4. Frequency distribution of the technical efficiency achievement of smallholder Arabica coffee farming in Panti Subdistrict, Jember

\begin{tabular}{lcr}
\hline Technical efficiency value & Farmer number & Percentage \\
\hline$<0.50$ & 3 & 8.82 \\
$0.51 \leq \mathrm{ET} \leq 0.60$ & 3 & 3.82 \\
$0.61 \leq \mathrm{ET} \leq 0.70$ & 11 & 17.65 \\
$0.71 \leq \mathrm{ET} \leq 0.80$ & 6 & 26.47 \\
$0.81 \leq \mathrm{ET} \leq 0.90$ & 9 & 5.88 \\
$0.91 \leq \mathrm{ET} \leq 1.00$ & 2 & 100 \\
\hline Total & 34 & \\
\hline
\end{tabular}




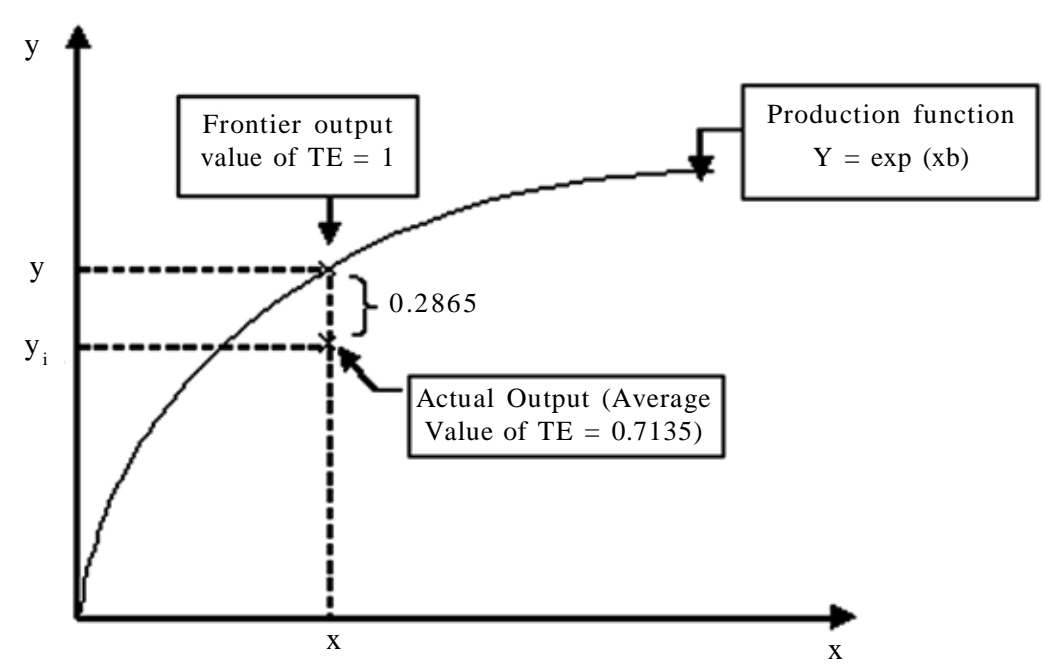

Figure 2. Technical efficiency achievement on frontier curve

By the assistances from ICCRI with proper instructions that technical efficiency of the Arabica coffee cultivation can be achieved. Since there were $50 \%$ of the farmers who were not technically efficient, the farmers ought to manage the inputs properly and correctly according to good agriculture practices (GAP) so that the inputs management could be efficient.

\section{Economic Efficiency Analysis}

Whole coefficient values were used to observe whether the Arabica coffee cultivation of smallholders in Panti Sub-district, Jember, had reached economic efficiency in their efforts. The achievement of economic efficiency could be seen through allocation efficiency approach. The value could acquire the comparison between the value of marginal product $(\mathrm{VMPX})$ and the price for each input or production factor used $\left(\mathrm{PX}_{\mathrm{i}}\right)$. Fitriani \& Zaini (2012) argued that economical production efficiency analysis was conducted by applying ratio indicator of marginal production value (VMP) with each price factor equally. The analysis results of economic efficiency of the Arabica coffee cultivation of smallholders in Panti Sub-district, Jember is presented in Table 5 .

Table 8 presented economical efficiency of each production factor that was used by the Arabica coffee cultivation of smallholder in Panti Sub-district of Jember District.

\section{Labor Force}

The ratio between marginal product and labor price was $-2.456 \times 10^{-9}$ meaning that management of labor force input in 5405 mandays was not economically efficient. Therefore, it is necessary to reduce labor force input to increase Arabica coffee production of smallholders in area studied. The value of marginal product indicated that adding one unit of labor force would decrease the income less than one rupiah, even though the condition still showed that the labor force had to be decreased because it was already in irrational Zone 2 beside make labor force management more economically efficient. 
Tabel 5. Results of calculation of the marginal product of smallholder Arabica coffee in Panti Sub-district Jember

\begin{tabular}{lrrrrrr}
\hline Variabel & \multicolumn{1}{c}{$\left.\mathrm{b}_{\mathrm{i}}\right)$} & \multicolumn{1}{c}{$\mathrm{X}_{\mathrm{i}}$} & $\mathrm{MPX}_{\mathrm{i}}$ & \multicolumn{1}{c}{$\mathrm{PX}_{\mathrm{i}}$} & $\mathrm{VMPX}_{\mathrm{i}}$ & \multicolumn{1}{c}{$\mathrm{EE}$} \\
\hline Labor $\left(\mathrm{X}_{2}\right)$ & $-0.786 \times 10^{-9}$ & 5,405 & $-1.228 \times 10^{-8}$ & 30,000 & $-7.367 \times 10^{-5}$ & $-2.456 \times 10^{-9}$ \\
Inorganic fertilizers $\left(\mathrm{X}_{4}\right)$ & 2.04 & 35,050 & 0,491 & 1,867 & 2,949 & 1.579 \\
Organic fertilizers $\left(\mathrm{X}_{5}\right)$ & $0.207 \times 10^{-8}$ & 89,250 & $1.958 \times 10^{-9}$ & 500 & $1.175 \times 10^{-5}$ & $2.350 \times 10^{-8}$ \\
\hline
\end{tabular}

\section{Inorganic Fertilizer}

The ratio between marginal production value and fertilizer price was 1.579 indicated that management of inorganic fertilizer as much of $35,050 \mathrm{~kg} / \mathrm{ha} /$ year was not economically efficient yet. Therefore, it was necessary to increase inorganic fertilizer input in order to increase the Arabica coffee production of smallholder in that area. The value of marginal product found meant that every inorganic fertilizer added per one unit would increase the marginal product by $0.491 \mathrm{~kg}$. The addition of inorganic fertilizer by one $\mathrm{kg}$ needed additional IDR.1,867.00 and would increase the income by IDR.2,949.00. Efficiency value by 1,579 could represent that the profit or the optimal output would be achieved if the management of inorganic fertilizer was corresponding to the optimal production analysis. Inorganic fertilizer application to reach optimal Arabica coffee production was $55,365 \mathrm{~kg} / \mathrm{ha} /$ year of inorganic fertilizer.

\section{Organic Fertilizer}

Ratio between value of marginal production and organic fertilizer price was smaller than 1 showed that the application of the organic fertilizer input in $89,250 \mathrm{~kg} /$ ha/year was not economically efficient. That number also show that it was necessary to add organic fertilizer input in order to increase the Arabica coffee production of smallholders in Panti Sub-district, Jember. The value of marginal product meant that every organic fertilizer added per one unit would decrease the marginal product by
$1.958 \times 10^{-9} \mathrm{~kg}$. Adding one unit of organic fertilizer would decrease the income less than one rupiah, neverless the condition still showed that the organic fertilizer had to be decreased because that was already in irrational Zone 2. Organic fertilizer reduction in organic fertilizer management resulted in more economically efficient.

According to the economic efficiency analysis result it can be concluded that the Arabica coffee cultivation in Panti Sub-district, Jember was not economically efficient yet, meaning that the Arabica coffee cultivation in that area had not allocated the inputs accurately and not been capable to produce in production level where that had positive value of marginal production which right to the maximum production point or in a point where the addition inputs in this point would bring reduction in production. The economic efficiency analysis result showed the necessity to add inorganic fertilizer and to reduce labor force and organic fertilizer in order to reach the optimal condition. The farmers ought to encourage themself to take risks in order to allocate inputs and costs to reach optimal condition (economic efficiency) of the Arabica coffee cultivation in Panti Subdistrict.

\section{CONCLUSION}

Arabica coffee production in Panti Subdistrict, Jember, was influenced by labor force factor, inorganic and organic fertilizers. The labor force variable caused negative influence on Arabica coffee production while inorganic fertilizer variable and organic 
fertilizer positively influence on coffee production. Technical efficiency of the Arabica coffee cultivation in Panti Sub-district, Jember, was $71.4 \%$ meaning that there was still less then $30 \%$ of potential production which could still be acquired by applying the combination of labor force, inorganic and organic fertilizer applications. There were $50 \%$ of the farmers who had already achieved that technical efficiency. Application of inorganic fertilizer had not been economically efficient, it was necessary to apply inorganic fertilizer input while labor force and organic fertilizer inputs had not been economically efficient.

\section{REFERENCES}

Asmara, R. \& S.K. Sugianto (2009). Analisis efisiensi teknis pada usahatani tebu. HABITAT, 20, 62-73.

Coelli, T.; D.S.P. Rao \& G.E. Battese (1998). An Introduction to Efficiency Productivity Analysis. Kluwer Academic Publishers, Massachusetts.

Coelli, T.; J.C. O'Donnel; G.E. Battese \& P. Rao (2005). An Introduction to Efficiency and Productivity Analysis. Springer, USA.

BPS (2015). Produksi Tanaman Perkebunan. Badan Pusat Statistik, Jakarta.

BPS Jatim (2013). Produksi Perkebunan Kopi 2006-2013. Badan Pusat Statistik Jawa Timur, Surabaya.

Darmansyah, A.N.; K. Sukiyono \& S. Sugiarti (2013). Analisis efisiensi teknis dan faktor yang mempengaruhi efisiensi pada usaha tani kubis di Desa Talang Belitar Kecamatan Sindang Dataran Kabupaten Rejang Lebong. AGRISEP, $12,177-194$.

Disbun Jatim (2014). Luas Areal dan Produksi Tanaman Perkebunan. Dinas Perkebunan Jawa Timur, Surabaya, Indonesia.

Dishutbun Jember (2014). Produksi Kopi Kabupaten Jember. Dinas Kehutanan dan Perkebunan Kabupaten Jember, Jember.

Fauziyah, A. (2010). Analisis efisiensi teknis usahatani tembakau : Suatu kajian dengan menggunakan fungsi produksi Frontier Stochastic. Embryo, 7, 1-7.

Fitriani \& M. Zaini (2012). Efisiensi ekonomis usaha pembesaran ikan lele. ESAI, 6 , 1978-6034.

Ghozali, I. (2011). Ekonometrika: Teori, Konsep dan Aplikasi dengan SPSS 17. Badan Penerbit Universitas Diponegoro, Semarang.

Harianti, A.; M.S. Veronica; Nur; S. Setiawan \& D. Iskandar (2012). Statistika II. Andi, Yogyakarta.

Jumiati, E \& I.M. Sekar (2014). Efisiensi teknis usahatani kopi di Kabupaten Tana Tidung (KTT). Agrifor, 13, 155-164.

Lains, A. (2003). Ekonometrika : Teori dan Aplikasi Jilid 1. Pustaka LP3ES, Jakarta.

Mandei, J.R. (2015). Efisiensi Teknis Usahatani Jagung di Kecamatan Remboken Kabupaten Minahasa. ASE, 11, 28-37.

Muflikah, Z. (2015). Analisis Produksi dan Prospek Pengembangan Budidaya Tembakau Bawah Naungan (TBN) di PTPN X Kebun Ajong Gayasan Jember. Skripsi, Fakultas Pertanian, Universitas Jember, Jember.

Nakanwagi, T.T. \& T.S. Hyuha (2015). Technical efficiency of milk producers in Cattle Corridor of Uganda: Kiboga District case. Modern Economy, 6, 846-856.

Nur, A.M.; P. Rahardjo; R. Hulupi; S. Abdoellah; G. Suprijadji; B. Odang; Saidi; S. Wiryadiputra \& C. Ismayadi (2015). Pedoman Teknis Budidaya Tanaman Kopi. Pusat Penelitian Kopi dan Kakao Indonesia, Jember.

Paludi, S. (2009). Identifikasi dan pengaruh keberadaan data pencilan atau outlier. Ilmiah Panorama Nusantara, 4, 56-61.

Rachmina, D. \& Maryono (2008). Analisis efisiensi teknis dan pendapatan usahatani padi 
program benih bersertifikat: Pendekatan stochastic production frontier. Agribisnis dan Ekonomi Pertanian, 2, 11-19.

Rakhmawati, K.P.; E. Hasrati \& E. Sumastuti (2011). Analisis efisiensi usahatani sawi caisim (Brassica juncea L.) Studi kasus di kelompok tani agribisnis "Aspakusa Makmur" Teras Kabupaten Boyolali. Agromedia, 29, 1-18.

Risandewi, T. (2013). Analisis efisiensi produksi kopi Robusta di Kabupaten Temanggung (Studi kasus di Kecamatan Candiroto). Litbang Provinsi Jawa Tengah, 11, 87-102.

Rukmana, R. (2015). Untung Selangit dari Agribisnis Kopi. Lily Publisher, Yogyakarta.

Sandjaja, B. \& A. Heriyanto (2011). Panduan Penelitian. Prestasi Pustaka, Jakarta.

Setiawan \& D.E. Kusrini (2010). Ekonometrika. ANDI. Yogyakarta.

Soekartawi (2013). Agribisnis Teori dan Aplikasinya. Rajawali Pers. Jakarta.
Sugiyono (2008). Metode Penelitian Kuantitatif, Kualitatif dan $R \& D$. ALFABETA. Bandung.

Sukiyono, K. (2005). Faktor penentu tingkat efisiensi teknik usahaani cabai merah di Kecamatan Sepulu Rejang, Kabupaten Rejang Lebong. Agroekonomi, 23, 176-190.

Thamrin, S. (2014). Faktor-faktor yang mempengaruhi usahatani kopi Arabika di Kabupaten Enrekang Sulawesi Selatan. Agric, 26, 1-6.

Wibowo, R. (2000). Ekonometrika Analisis Data Parametrik. Fakultas Pertanian, Universitas Jember, Jember.

Winarni, E.; R.D. Ratnani \& I. Riwayati (2013). Pengaruh jenis pupuk organik terhadap pertumbuhan tanaman kopi. Momentum, 9, 35-36.

$$
* * 0 * *
$$

